\title{
Fungal metabolites as a natural source of herbicide: a novel approach of weed management
}

\author{
Ajay Kumar Singh* \\ Mycological Research Laboratory, Department of Biological Science, Rani Durgawati \\ University, Jabalpur-482001 (Madhya Pradesh), India \\ Akhilesh Kumar Pandey \\ Mycological Research Laboratory, Department of Biological Science, Rani Durgawati \\ University, Jabalpur-482001 (Madhya Pradesh), India \\ ${ }^{*}$ Corresponding author. E-mail: drajay2009@gmail.com
}

\begin{abstract}
Weeds are undesirable vegetation directly or indirectly inferring with human welfare. Conventional methods of weed control have failed due to one or other reason. Herbicideresistant weeds are the main problem in weed control due to the number of weed biotypes resistant to herbicides that constantly increases by the continuous use of the same products for years. Development of alternative weed control methods is needed to help decrease reliance on herbicide use. Biological weed control is an alternative option for weed problems, particularly in agriculture and forestry. It is based on the use of natural enemies, particularly insects and pathogens to control weeds, as a sustainable, low cost and more environmentally acceptable method of weed control. One of the approaches to biological weed control using fungal phytotoxin applied in similar ways to conventional herbicides. Fungal phytotoxins are natural secondary metabolites produced by plant pathogenic fungi during host-pathogen interactions. They have received considerable particular attention for elucidating disease etiology, and consequently to design strategies for disease control. Due to wide differences in their chemical structures, these toxic metabolites have different ecological and environmental roles and mechanisms of action. This review aims at summarizing the studies on the possible use of fungal phytotoxin as a lucrative, novel source of secondary phytotoxic herbicidal compounds for management of broad spectrum, noxious and pernicious weeds.
\end{abstract}

Keywords: Fungal metabolites, Natural metabolites, Phytotoxin, Weed control

\section{Article Info}

DOI: 10.31018/jans.v11i1.1994 Received: January 17, 2019 Revised: February 18, 2019 Accepted: February 24, 2019

\section{How to Cite}

Singh, A. K. and Pandey, A.K. (2019). Fungal metabolites as a natural source of herbicide: a novel approach of weed management. Journal of Applied and Natural Science, 11 (1): $158-163$

\section{INTRODUCTION}

Weeds are a significant problem in crop production and their management is crucial for modern agriculture to avoid yield losses and to ensure food safety. They are unwanted and undesirable plants, which interfere with the utilization of land and water resources and thus, adversely affect human welfare. These are an integral part of all cropping ecosystems and serve as a major biological constraint preventing crops from achieving their yield potentials. Conventional methods of weed control have failed due to one or other reasons and therefore, there is an urgent need for an alternative strategy. However, the idea has lain dormant for several decades and problems arises due to indiscriminate use of chemical herbicides viz., environmental pollution, development of resistance, transportation and disposal of byproducts forms during synthesis and high rocketing cost etc again attracted the attention of large group of scientists world over. Over the past few years there has been a renewed interest in the development of eco-friendly alternatives of chemical pesticides. This has been driven by an increasing public awareness, first championed by Carson (1962) in her book - Silent Spring, of the environmental and human health effects of synthetic chemicals. The world is now profoundly aware of the issues of acute mammalian toxicity, the potential for cancer, the polluting effects of non-degradable or slowly degrading chemicals and the existence of pesticide residues on foods. Thus, there is an urgent need for an alternative approach to pest management that can complement and partially replace current chemically based management practices. Many research teams were devoted to develop alternative strategies based on the use of natural products and in particular on the use of fungal phytotoxin alone as natural herbicides and in combination with the fungal spores in a more efficient integrated management (Rimando and Duke, 2006; Beck et al., 
2013; Vurro et al., 2009).

The idea of using plant pathogens to control weeds is almost as old as the science of plant pathology itself. The search for natural products with novel herbicidal activities is of great importance for agriculture, since most existing herbicides are either banned or inefficient due to resistant weeds, and the flow of novel herbicides identified by classical chemical screening is dramatically reduced.

Since the initial definition this concept the term Mycoherbicide which was introduced by Daniel et al., (1973) has been redefined as plant pathogenic fungi developed and used in inundative strategy to control the weeds in the way chemical herbicides are used or their byproduct that control specific weeds in agriculture as effectively as chemicals (TeBeest and Templeton 1985).

Theoretically all the classes of plant pathogens have herbicidal potential but fungi appear most promising due to their strong mechanism of action. They can gain entry into the host without the assistance of vector. Fungi that are virulent, host specific and genetically stable but constrained naturally by low inoculums production and poor dissemination are probably the best candidate for exploitation in weed management systems (Charudattan, 1991). Biorational approach is the use of toxic secondary metabolites of fungi which are considered to be safest pesticides for the environment and people. Possibilities of exploitation of Fungal toxins as herbicides have been reviewed in many publications (Barbosa et al., 2009a; Cantrell et al., 2012; Dayan et al., 2009; Demuner et al.,2006; Duke et al., 2000, 2002; Passos et al., 2010). Fungal phytotoxins are secondary metabolites that play an important role in the induction of disease symptoms on Crops and weeds (Graniti et al., 1989; Ballio and Graniti, 1991; Evidente and Motta, 2001; García-Pajón and Collado, 2003; Strange, 2007; Möbius and Hertweck 2009; Varejão et al., 2013; Schueffler and Anke, 2014). They belong to different classes of naturally occurring compounds as: aromatic, aminoacids, coumarins and isocoumarins, cytochalasans, ethanones, furopyrans, nonenolides, oxazatricycloalkalenones, pyrones, spirophytotoxins, terpenes, trichothecenes, and some others with a complex and original carbon skeleton (Evidente and Motta, 2001; García-Pajón and Collado,2003),

Weed management by fungal metabolites: Weeds constitute one of the small but problematic groupd of plants exhibiting a great taxonomic diversity. They are the least cared for yet they grow luxuriantly and abundantly in different ecosystems owing to their unique set of traits that make them stronger than the nurtured crops. Weeds, especially the invasive ones, due to their greater adaptability are very successful and grow at the cost of other vegetation. They are nuisance, particularly in agro ecosystems, where they compete with crop plants for resources and cause huge economic losses.. Conventional methods of weed control have failed due to one or other reasons. The weed management relied greatly on herbicides to provide an easy, efficient and reliable method of weed control. The indiscriminate use of herbicides is counterproductive to environment and human health. Thus an urgent need exists to get ride of adverse effects of weeds without affecting the natural balance. Biological control through fungi attracted the attention of scientists' world over. Fungi that are virulent, host specific and genetically stable, but constrained by low inoculum production and poor dissemination is considered to be the best candidates for their development as herbicides. The fungi constitute a most fascinating group of plants exhibiting great diversity in form, structure, habit, life history, mode of nutrition and pathogenesis. They show a wide range of parasitism. Some are totally saprophytes while many of them are obligate pathogens to a specific host. They have strong mechanisms of pathogenesis and responsible for several devastating diseases in more or less all the groups of living organisms. Such characteristics of some fungi have been exploited in the management of obnoxious pests' viz., weeds, insects, plant pathogens etc.

Diversity of fungi constitutes the most extraordinary reservoir of life in the biosphere that we have only just begun to explore and understand. Out of 69000 species and genera of fungi recognized only very meager number of species has been evaluated for their mycoherbicidal potential. Most of the mycoherbicide candidates tested belong to Deuteromycetes, a large and varied class of conidial non-sporulating fungi. Species of Colletotrichum, Alternaria, Septoria, Phompsis, Phoma, Phaeoseptoria, Ascochytaetc are the major genera developed as mycoherbicides. Another important area of exploitation of pathogens and exopathogens i.e., phytotoxic metabolites produced by them is still ignored by the weed researchers while the potential of such organisms in the production of a variety of phytotoxins are well known in pathological literature. Therefore, the phytotoxic potential of secondary metabolites of microorganisms associated with weedshasattracted the attention of a large number ofscientists world over (Hoagland, 1990, 1999; Vikrant et al., 2006). The secondary metabolites appear to be a lucrativesource of novel structures having unique mode of action which could be exploited as commercial herbicides directlyor as their derivatives (Abbas et al., 1992). Several microbial products viz., Bialaphos, Gulfosinate, Tentoxin, Cornexistin, AALtoxins, Fumonisin, Moniliformin etc have been successfully exploited forthe management of many weeds (Hoagland, 2001; Barbosa et al., 
2002). Thus this article aimed to highlight the potential of fungi as Mycoherbicide and as a lucrative, novel source of secondary phytotoxic herbicidal compounds for management of broad spectrum, noxious and pernicious weeds.

The rational behind this approach is the use of toxic secondary metabolites of fungi, which are considered to be the safest pesticides for the environment and people. Possibilities of exploitation of microbial toxins as herbicides have been reviewed in many publications (Demuner et al., 2006; Evidente et al., 2008abc, 2009; Yuzikhin et al., 2007; Pedras et al., 2009). To overcome the problem of environmental dependency of mycoherbicides this approach has been developed. Isolation of natural herbicidal constituents from culture filtrates of plant pathogenic and other fungi (Palmer et al. 2005 ) is one of the alternative strategies to man- age the weeds. Phytotoxins are usually isolated from in vitro cultures of the pathogen grown on either solid or liquid media (Strange, 2007). Microbial toxins unlike conventional synthetic pesticides, which are classified on the basis of their chemistry, biorational pesticides are grouped on the basis of some shared characteristics. For example, they pose minimal to no risk to the environment due to their chemical make-up, rapid degradation or the small amounts required for effective control. Both pathogenic as well as non-pathogenic fungi are known to synthesize array of phytotoxic metabolites mentioned in Table 1. Some of them have been evaluated, patented and few of them have been commercialized as herbicides. Significant herbicidal activity of partially purified filtrate (CFCF) of C. gloeosporioides f. sp. parthenii FGCC \#18, C. dematium, FGCC\#20, F. ox-

Table 1. Phytotoxic metabolites with promising herbicidal properties.

\begin{tabular}{|c|c|c|}
\hline S.No & Fungal Source & Phytotoxin \\
\hline 1 & Alternaria alternata & Maculosin \\
\hline 2 & Alternaria alternata & Tentoxin* \\
\hline 3 & Alternaria alternata & AAL- toxin* \\
\hline 4 & Alternaria alternata & Tenuazonic acid \\
\hline 5 & Alternaria eichhorniae & Peryleneginones, Alteichin \\
\hline 6 & Alternaria kikuchinana & AK-Toxin \\
\hline 7 & Alternaria mali & AM -Toxin \\
\hline 8 & Alternaria porri & Porrolide* \\
\hline 9 & Alternaria helianthi & Radicinin \\
\hline 10 & Alternaria zinnia & Zinniol \\
\hline 11 & $\begin{array}{l}\text { Bipolariscynodonti; } \quad \text { Phomadistruciva;Phomaexigua; } \\
\text { Penicilliumroqueforti }\end{array}$ & Ermophilans \\
\hline 12 & Cercosporakikuchi & Cercosporin \\
\hline 13 & Fusarium moniliforme & Moniliformin* \\
\hline 14. & Fusarium sp & Fusaric acid* \\
\hline 15. & Fusicocumamygdale & Fusicocin \\
\hline 16. & Colletotrichum tabacum; C. nicotianae & Colletotrichin \\
\hline 17. & Rhizoctoniasolani & Gliotoxin \\
\hline 18. & Ascochytahyalospora & Aschochytine, Pyrenolide-A, Hyalopyrone \\
\hline 19. & A. cypricola & Cyperine \\
\hline 20. & $\begin{array}{l}\text { Dreschlera maydis; Dreschleraoryzae, } \\
\text { Dreschlerasorghicola }\end{array}$ & $\begin{array}{l}\text { OphiobilinsI, A, C. Epihydroophiobolin A, 6- } \\
\text { Epiophiobolin }\end{array}$ \\
\hline 21. & Dreschlerasorokiana, Bipolaris sp. & Perhelminthosporol \\
\hline 22. & Dreschleraindica & Curvulins \\
\hline 23. & Dreschleranodulosum & Tryptophol \\
\hline 24. & Peacilomycesvariotii & Cornexistin \\
\hline 25. & Gliocladiumvirens & Viridiol \\
\hline 26. & Penicillium charlesii & Citreoviridin \\
\hline 27. & Helminthosporiumcarbonum & HC- Toxin \\
\hline 28. & Streptoverticilliumsp & Cyclocarbamide A, B \\
\hline 29. & Cochliobolusspicifer & Spiciferones A, B, C \\
\hline 30 & Chaetomium globosumi & Chaetoglobosins \\
\hline 31 & Aspergillus ustus & Dihydropergillin \\
\hline 32 & Aspergillusniger, Aspergillus glaucus & Nigerazine A, B \\
\hline 33 & Aspergillusniger & Orlandin, Kotanin \\
\hline 34 & Aspergilluscandidus & Terphenyllin, Hydroxy terphenyllin \\
\hline 35 & Aspergillusterreus, & Mevinolin, Acetylaranotin \\
\hline 36 & Cephalosporiumrecifei, A. flavus, & Macrolides \\
\hline 37 & Chaetomium trilaterale & Oosporein \\
\hline 38 & Myrothecium verrucaria; Myrothecium roridum & Trichothecones \\
\hline
\end{tabular}

* =Patented, Source: Pandey, 1999 
ysporumFGCC\#39, F. solaniFGCC\#86, S. rolfsiiFGCC\#19, Aspergillus flavus FGCC\#14 and CurvularialunataFGCC\#41 have been observed against $P$. hysterophorus (Thapar et al., 2002; Pandey et al., 2003, 2004 b) and Lantana camara (Saxena and Pandey 2000; Pandey et al., 2002). Saxena and Pandey (2001) reported very high biological activity in CFCF of Alternaria alternata FGCC\#25 against L.Camara. Pandey et al (2007) reported very high biological activity in CFCF of HelminthosporiumspFGCC\#74against Hyptissuaveolens. Singh 2007 reported herbicidal compounds from some selected fungi against different noxious weeds. Alternaria eichhorniae metabolites Perlenginones and Alteichin has shown good potential agent Water hyacinth weed.

Future prospects: Out of several microbial strains and their metabolites tried, only few strains or species have been exploited commercially and sold in market with different trade names. Today's market of biopesticides only represents less than $1 \%$ of a total worldwide pesticide market approaching 39billion dollar annual sales. Several indigenous strains of microorganism have been commercialized The main hindrance in the use of microbes other than fungi as Microbial Pesticides are the requirement of vector, difficulty in mass production and field application, inability of direct penetration of host, environmental dependency and their low commercial perspectives. Many naturally occurring strains of phytopathogens such as bacteria are still awaiting opportunity for even their preliminary evaluation as herbicides. It is likely with further refinement although, there are few major constraints, which drastically influence the development of modern techniques and closer cooperation among mycologists, Pathologists, Analytical chemists, Weed scientists and Engineer. Similarly research on virus - enhancer interrelationship will provide us a better understanding. In addition to this investigating systems where the brightener is a virus enhancer (gypsy moth and gypsy moth NPV) and where the effect is slight (corn earworm and corn earworm NPV) provides better insights into host susceptibility and virus activity. Several non-pathogenic strains of fungi, bacteria and actinomycetes have proved to be the most accessible source of novel by-products. Tremendous effort has been expanded in chemically characterizing several metabolites of these microbes, yet comparatively very little effort has been made to determine their herbicidal potential. Although, there are few major constraints, which drastically influence the development of microbial based pest control technology, but its future potential is enormous. The scientists should work in the field of discovery of more potential agents, development of rapid and easy methods of evaluation, production and formulation. The increased demand for chemical herbicide for agricultural production, coupled with the growing number of biotypes of herbicide-resistant weeds, so there is great demand for discovering new compounds with new mechanisms of action for weed control. Plant pathogenic fungal phytotoxins have great potential to meet both needs (Dayan et al., 2011; Abbas and Duke, 1997). Fungal natural compounds present a great potential as natural herbicides. Today future research are driving modern agriculture towards crop production systems that are healthier, safer, and friendlier to the environment as consumers demand pesticide-free products and environmentally-safe cultural practices. Taking into account these perspectives, the richest sources of natural compounds present in nature and their ecology, assume higher and higher importance and can increase the possibility of finding natural herbicides with new scaffolds and modes of action, fundamental factors overcoming resistance in weeds to conventional, synthetic herbicides. Being the result of co-evolution of the producing organism and its biotic environment, these compounds can have high target selectivity, with potentially reduced risks for humans and nontarget organisms. Furthermore, they can have a shorter environmental half-life than synthetic compounds, thus reducing potential environmental impact.

\section{Conclusion}

In the search for alternative solutions to weed control, the interest in application of bioactive secondary metabolites has increased. The success of natural products or natural product derived products in weed management is weak compared to that for insecticide and fungicide. The biochemical or biorational herbicide available for organic farmers and those who wish to reduce synthetic herbicide use are ineffective and costly to use. In this review, we found that original culture filtrates were applied in the foliar spray bioassays showed good results. It is likely that if these culture filtrates are used in a concentrated form, these will be more toxic to weed species. Further studies are required to isolate the active herbicidal constituents from these fungal culture filtrates. Several natural phytotoxins have novel mode of action. Thus, the growing need for new biochemical herbicide for organic agriculture and herbicides with new herbicides mode of action for conventional agriculture are both drivers for intensification of research into natural products as herbicides or templates for synthetic herbicides. For a successful research and development process leading to a commercial product, a wide range of criteria (biological, environmental, toxicological, regulatory, and commercial) must be satisfied from the beginning. Among the major challenges to be faced by the candidate products to reach the market are the sustainable use of raw materials, the standardization of chemi- 
cally complex extracts, and the regulatory requirements and approval. The unique set of secondary metabolites produced by fungi may play an important role in weed management as new products directly, as novel chemical frameworks for synthesis and/or for identifying original modes of action. The application of fungal phytotoxic metabolite could be a replacement for synthetic herbicide which is more economical in controlling weeds than the synthetic herbicides. We are confident that the future of fungal metabolites-based herbicide will accelerate agriculture production and serve as an alternative to the chemical herbicides because of its safety in the environment. The tremendous structural diversity and the promising herbicidal potential of many of these natural products reported in this current review will prompt a continued interest in developing fungal metabolites as natural safe herbicides.

\section{ACKNOWLEDGEMENTS}

We are thankful to the Head, Dept of Biological Sciences. Financial assistance received from Council of Scientific and Industrial Research (CSIR) is also thankfully acknowledged.

\section{REFERENCES}

1. Abbas, H. K., Vesonder, R. F., Boyette, C.D., Hoagland, R.E. and Krick, T. (1992). Production of fumonisins by Fusarium moniliforme culture isolated from Jimson weed in Missisipi. J. Phytopathol.136: 199-203.

2. Abbas, H.K. and Duke, S.O. (1997. Plant pathogens and their phytotoxins as herbicides. Pp. 1-20. In: Toxins in Plant Diseases Development and Evolving Biotechnology. Upadhyay, R.K. and Mukherjee, K.G. (Eds.) Oxford and IBH Publishing Co. Pvt. Ltd. New Delhi

3. Ballio, A. and Graniti, A. (1991). Phytotoxins and their involvement in plant disease. Experientia, 47: 751-826.

4. Barbosa, L.C.A., Teixeira, R.R., Montanari, R.M. (2009a). Phytotoxic natural products asmodels for the development of crop protection agents. In: Epifano, F. (Ed.), Current Trends in Phytochemistry. Research Singpost, Kerala, pp. 21-59.

5. Barbosa, A., Souza, C. G. M., Dekker, R.F.H., Fonseca, R.C., Ferreira,D.T. (2002). Phytotoxin produced by Bipolaris euphorbiae in-vitro is effective against the weed Euphorbia heterophylla. Brazilian Archives of Biology and Technology, 45: 233-240

6. Beck, J. J. Coat, J. R. Duke, O. S. and Koivunen, M. E. (2013). In: Pest Management with Natural Products, ACS Symposium Series 1141, ACS Division of Agricultural Inc., Washington, USA,

7. Cantrell, C.L., Dayan, F.E., Duke, S.O., 2012. Natural products as sources for newpesticides. Journal of Natural Products, 75: 1231-1242

8. Carson, R., (1962). In: Silent Spring. Houghton Mifflin Harcourt; Boston.

9. Charudattan, R.( 1991). The mycoherbicide approach with plant pathogens. In: Microbial Control of Weeds, ed D.O. Tebeest, Chapman and Hall, New York, USA, pp.24-57.
10.Daniel, J.T., G. E. Templeton, R.J., Smith, Jr., and W. T. Fox. (1973). Biological control of northern Joint vetch in rice an endemic fungal disease. Weed Sci.21: 303-307.

11.Dayan, F.E., Cantrell, C.L., Duke, S.O., (2009). Natural products in crop protection. Bioorganic and Medicinal Chemistry 17, 4022-4034.

12.Dayan, F.E., Owens, D.K., Due, S.O., (2011). Rationale for a natural products approach to herbicide discovery. Pest Management Science 68, 519-528.

13.Demuner, A.J., Barbosa, L.C.A., Veiga, T.A.M., Barreto, R.W., King-Diaz, B., Lotina-Hennsen, B., (2006). Phytotoxic constituents from Nimbya alternantherae. Biochemical Systematic and Ecology 34, 790-795.

14.Duke, S.O. (1986). Naturally occurring chemical compounds as herbicides. In: Review of Weed Science. Vol 2. Weed Science Society of America. Champaign, Illinois. Pp. 17-44.

15.Duke, S.O., Dayan, F.E., Rimando, A.M., Schrader, K.K., Aliotta, G., Oliva, A., Romagni, J.G., (2002). Chemicals from nature for weed management. Weed Science 50: 138-151.

16. Duke, S.O., Romagni, J.G., Dayan, F.E. (2000). Natural products as sources for newmechanisms of herbicidal action. Crop Protection 19: 583-589.

17. Evidente, A. and Motta, A. (2001). In Bioactive Compounds from Natural Products, ed. C. Tringali, Taylor and Francis, London, pp. 473-525.

18.Evidente, A., Cimmino, A., Andolfi, A., Vurro, M., Zonno, M.C., Cantrell, C.L., Motta, A. (2008c). Phyllostictines A-D, oxazatricycloalkenones produced by Phyllostictacirsii, a potential mycoherbicide for Cirsium arvense bio-control. Tetrahedron 64: 16121619.

19.Evidente, A., Cimmino, A., Berestetskiy, A., Andolfi, A., Motta, A., (2008b). Stagonolides G-I and modiolide A, nonenolides produced by Stagonospora cirsii, a potential mycoherbicide for Cirsium arvense. Journal of Natural Products 71: 1897-1901.

20.Evidente, A., Cimmino, A., Berestetskiy, A., Mitina, G., Andolfi, A., Motta, A., (2008a).Stagonolides B-F, nonenolides produced by Stagonospora cirsii, a potential mycoherbicide of Cirsium arvense. Journal of Natural Products 71: 31-34

21.Evidente, A., Punzo, B., Andolfi, A., Berestetskiy, A., Motta, A., (2009). Alternethanoxins A and B, polycyclic ethanones produced by Alternaria sonchi, potential mycoherbicides for Sonchus arvensis biocontrol. Journal of Agriculturaland Food Chemistry 57: 66566660

22.García-Pajón, C. M. and Collado, I. G. (2003). Secondary metabolites isolated from Colletotrichum species. Nat. Prod. Rep., 20: 426-431

23.Graniti, A. Durbin, R. D. and Ballio. A. (1989). Phytotoxins and Plant Pathogenesis, Springer-Verlag, Berlin, NATO ASI Series, Series H, vol. 2

24. Hoagland, R.E. (1990). Microbes and Microbial Products as herbicides: An overview. Amer. Chem. Symp. Ser. No. 439, Washington, D.C., American Chemical Society: $2-52$

25. Hoagland, R.E. (1999). Plant pathogens and microbial products as agents for biological weed control. Pp. 214-255. In: Advances in Microbial Biotechnology. Tiwari, J.P., Lakhanpal, T.N., Singh, J., Gupta, R. and Chamda, B.P. (Eds.) APH Publishing Co., New Delhi, India

26. Hoagland, R.E. (2001). The genus Streptomyces. A 
rich source of novel phytotoxins. In: Ecology of Desert Environments (ed. Ishwar Prakash) Scientific Publishers, Jodhpur, India: 139-169

27.Möbius, N. and Hertweck, C. (2009). Fungal phyototoxins as mediators of virulence. Curr. Opinion Plant Biol., 12: 390-398

28.Palmer, C. S., J. A. Saleeba, and B. R. Lyon (2005).Phytotoxicity on cotton explants of an $18.5 \mathrm{kDa}$ protein from culture filtrates of Verticillium dahliae. Physiol. Mol. Plant. Pathol.,67: 308-318

29.Pandey, A. K. Rekha Sharma, Sadaf Quereshi and Ajay K Singh (2007). Herbicidal Potential of Cell Free Culture Filtrate of Helminthosporium sp FGCC\#74 against Hyptis suaveolens. J. Basic. Appl. Mycol., 6 (landII): 89-93

30.Pandey, A. K., A. K. Singh, Sadaf Quereshi and Deepa Agrawal (2004b). Herbicidal activities of secondary metabolites of Strepomyces sp. against Hyptis suaveolens. J. Basic. Appl. Mycol., 3: 95-97

31.Pandey, A. K., G. M. Shrivastava, A. K. Singh and S. K. Verma (2003). Herbicidal potential of secondary metabolites of Sclerotium rolfsii against Parthenium: A preliminary observation. J. Basic Appl. Mycol., 2 (1): $27-30$

32.Pandey, A.K. (1999). Herbicidal potential of microorganism: Present status and future prospects. pp. 87105. In: Microbial Biotechnology for Sustainable Developments and Productivity. Rajak, R.C. (Ed.) Scientific Publications, Jodhpur, Rajsthan, India

33.Pandey, A.K., Chandla, P. and Rajak, R.C. (2002). Herbicidal potential of secondary metabolites of some fungi against Lantana camara L. J. Mycol. Plant Pathol. 32 (1): 100-102

34.Passos, J.L., Barbosa, L.C.A., Demuner, A.J., Barreto, R.W., King-Diaz, B., Lotina-Hennsen, B., (2010). Effects of Corynesporacassiicola on Lantana camara. Planta Daninha 28: 229-237.

35.Pedras, M.S.C., Chumala, P.B., Jin, W., Islam, M., Hauck, D.W., (2009). The phytopathogenic fungus Alternaria brassicicola: phytotoxin production and phytoalexin elicitation. Phytochemistry, 70: 394-402
36.Rimando, A. M. and Duke, O. S. (2006). In: Natural Products for Pest Management, Symposium Series 927, ACS Division of Agricultural and Food Chemistry, Inc., Washington, USA, ch. 1, pp. 2-21.

37.Saxena S., Pandey A.K. (2000). Preliminary Evaluation of fungal metabolites as natural herbicides for the management of Lantana camara. Indian Phytopathol., 53 (a): 490-493.

38.Saxena, Sanjai and A. K. Pandey (2001). Microbial metabolites as ecofriendly agrochemicals for the next millennium.Appl.Micrbiol.Biotechnol. ,55: 395-403

39.Schueffler, A. and Anke, T. (2014). Fungal natural products in research and development Nat. Prod. Rep., 31: 1425-1448

40.Singh, A. K. (2007). Isolation and characterization of herbicidal compounds from some selected fungi. Ph.D Thesis. Bioscience. R.D. University, Jabalpur

41.Strange, R. N. (2007). Phytotoxins produced by microbial plant pathogens. Nat. Prod. Rep.,24: 127-144

42.TeBeest, D. O., and Templeton, G.E. ( 1985). Mycoherbicides: Progress in biological control of weeds. Plant Dis. 69:6-10.

43. Thapar, R., A.K. Singh, Archana Pandey and A.K. Pandey (2002). Bioactivity of CFCF of Curvularialunata in Parthenium hysterophorus L. J. Basic Appl. Mycol.1(1): 126-129

44.Varejão, E. V. V., Demuner, A. J. , Barbosa, L. C. A. and Barreto, R. W. (2013). The search for new natural herbicides: Strategic approaches for discovering fungal phytotoxins. Crop Protection, 48: 41-50

45.Vikrant, P. 2002. Management of Parthenium employing secondary metabolites of Phomaherbarum FGCC\#75. M. Sc. Biochemistry Dissertation, R.D.University, Jabalpur.

46. Vurro, M., Boari, A., Evidente, A., Andolfi, A. and Zermane, N. (2009). Natural metabolites for parasitic weed management. Pest Manag. Sci., 65: 566-571

47.Yuzikhin, O., Mitina, G., Berestetskiy, A., (2007). Herbicidal potential of stagonolide, a new phytotoxic nonenolide from Stagonospora cirsii. Journal of Agricultural and Food Chemistry, 55: 7707-7711. 